\title{
Sustainable competitive advantage strategy in hospital industry to response policy change in Indonesia: A narrative review
}

\author{
Marselli Widya Lestari ${ }^{*} \mathbb{D}$, Antono Surjoputro ${ }^{2}$, and Ayun Sriatmi ${ }^{\mathbb{C}}$ \\ ${ }_{1}^{1}$ Program Magister Kesehatan Masyarakat, Faculty of Public Health, Diponegoro University, Semarang, Indonesia \\ ${ }^{2}$ Faculty of Public Health, Diponegoro University, Semarang, Indonesia
}

Doi: https://dx.doi.org/10.36685/phi.v7i3.421

Received: 23 May 2021 | Revised: 31 May 2021 | Accepted: 1 September 2021

Corresponding author:

dr. Marselli Widya Lestari, S.Ked

Program Magister Kesehatan Masyarakat, Faculty of Public Health

Diponegoro University, Semarang, Indonesia

Jl Jemursari no 51-57, Surabaya

Mobile: +6281703341579

Email: marselliwidya@gmail.com

Copyright: (c) 2021 the author(s). This is an open-access article distributed under the terms of the Creative Commons Attribution Non-Commercial License, which permits unrestricted non-commercial use, distribution, and reproduction in any medium provided the original work is properly cited.

\begin{abstract}
In response to policy changes, the hospital as an organization is expected to establish a strategy to stay afloat in business competition. However, the health industry, especially hospitals, has certain determinants that are different from other industries. This article is a literature review that focuses on business strategy management, namely sustainable competitive advantage in the hospital industry. This review is aimed at managers nowadays in building and maintaining their hospital positions. In conclusion, changes in strategy can be made specifically according to the type of hospital and positioning results.
\end{abstract}

Keywords: sustainable competitive advantage; hospitals; business competition; policy; Indonesia

\section{Introduction}

Since 2010, the regulations regarding hospital classification have continued to change. Minister of Health Regulation number 56 of 2014 is a ministerial regulation that refines and at the same time revokes Minister of Health Regulation number 147 of 2010 concerning hospital licensing and Minister of Health Regulation number 340 of 2010 concerning hospital classification, KMK 2264/MENKES/SK/XI/2011 concerning the implementation of hospital licensing. Then, in mid-2019, the Minister of Health Regulation number 30 of 2019 appeared, which regulates and reaffirms the qualifications of medical personnel, medical devices, and other medical support according to the assigned hospital class, as well as updating the previous ministerial regulation, namely the Minister of Health Regulation number 56 of 2014. However, the implementation of this regulation was postponed at the end of 2019 because it was deemed not suitable for our current situation. Early 2020, the new 2019-2024 Minister of Health, dr. Terawan Agus Putranto, Sp. Rad (K) ratified the Minister of Health Regulation number 3 of 2020 concerning hospital classification and licensing as a form of adjustment to the previous ministerial regulation that sparked many pros and cons. 
This policy change caused implications for the hospitals. In response to policy changes, hospitals as an organization are expected to review its strategies. This is done to find out whether the previous strategy is still relevant or needs adjustments. Moreover, the Minister of Health Regulation number 3 of 2020 established single rates and hospital classification based on only the number of beds (Kementerian Kesehatan Republik Indonesia, 2020). This situation requires the hospital to remain in business competition how the hospital can sustain and continue to compete in improving its services.

In business strategy management, the term competitive advantage is already well known, in which the ability a company gets through its characteristics and resources to have higher performance compared to other companies in the same industry and market (Chen \& Liao, 2011; Taie, 2014). This theory was coined by Michael Porter in his book entitled Competitive Advantage (1985). Currently, the theory of competitive advantage is being developed by many researchers, especially sustainable competitive advantage. Sustainable competitive advantage (SCA) is a strategy to maintain a company's superiority compared to other competitors (Chen \& Liao, 2011; Taie, 2014; Pirayesh \& Forouzandeh, 2016)

This article will discuss strategic management, namely sustainable competitive advantage (SCA) in the hospital industry. This is expected to give answers to the problems of managers nowadays in building and maintaining its company to remain successful in its class.

\section{Development}

Every organization strives to achieve an advantage over the competition. The competition becomes the trigger for change. If the organization cannot outperform its competitors in efficiency, quality, or ability to innovate products and services, it will not survive. Competition in the health industry, especially in hospitals, has certain determinants that are different from other industries. In health services, competitiveness is not only based on profit but also the uniqueness of the health sector, namely in terms of service quality and social function. In other words, a health organization can be considered a competitive advantage when it provides high-quality medical services, high-performance medical equipment, modern medical products and therapeutic procedures, comfortable conditions, and lower rates, reduced service costs, etc. Human resources also play an important role in reputation, professionalism, differentiation, and specialization. All of these aspects emphasize customer value. Customer value is useful for ensuring the success of health services in the industry (Taie, 2014)

Table 1 Literature Distribution

\begin{tabular}{lll}
\hline Author (year) & Location & Data \\
\hline Chen and Liao (2011) & Korea & 153 samples \\
Anyim (2012) & Nairobi & 30 out of 64 private hospitals \\
Gowen et al. (2012) & US & 210 hospitals \\
Taie (2014) & Egypt & 106 samples \\
Stefan et al. (2016) & Roma & 291 samples \\
Gautam and Ghimire (2017) & Nepal & 233 samples \\
Sweis et al. (2018) & Jordan & 56 samples \\
Ying et al. (2019) & Pakistan & 384 samples \\
Rahmantya and Djazuli (2019) & Indonesia & 115 samples \\
Singh et al. (2020) & India & Two informants \\
Susanto (2019) & Indonesia & Secondary data \\
Mahasneh et al. (2020) & Saudi Arabia & 40 private hospitals \\
\hline
\end{tabular}

According to Stefan et al. (2016), SCA in the hospital industry has four dimensions: economy/financial, quality, social, and strategy. Each of these dimensions has a determinant. The economic dimension consists of cost and efficiency. Hospitals are directed to provide resources (information, material, infrastructure, and financial resources) and efficient management according to patient needs. Susanto's research supports this. In his study Susanto (2019), it was stated that efficiency through co-branding and green health care was useful in increasing competitive advantage at Mitra Keluarga Hospital. Co-branding is a form of collaboration between two or more brands that already have 
significant consumer recognition. This can create a positive contribution to the efficiency and reduce the company's operating expense. Meanwhile, green health care is a concept combining development that does not damage the environment as well as the health service that does not pollute the environment. One of the principles of green health care is to reduce hazardous waste. With less waste generated by health facilities, resources are used more efficiently and reduce costs (Susanto, 2019).

Table 2 Dimensions and Factors Sustainable Competitive Advantage

\begin{tabular}{lll}
\hline No & Dimensions & Factors \\
\hline 1 & Economy & Cost, Efficiency (Stefan et al., 2016; Susanto, 2019) \\
\hline 2 & Quality & Service quality (Stefan et al., 2016; Sweis et al., 2018) \\
\hline 3 & Social & $\begin{array}{l}\text { Customer satisfaction and loyalty (Anyim, 2012; Stefan et al., 2016) } \\
\text { Human resources satisfaction (Stefan et al., 2016; Gautam \& Ghimire, 2017) }\end{array}$ \\
\hline & & Service differentiation (Anyim, 2012; Susanto, 2019) \\
& Innovation (Stefan et al., 2016) \\
& Strategy & Marketlectual capital (Taie, 2014; Stefan (Chen \& Liao, 2011) \\
\hline
\end{tabular}

The quality dimension is the service quality in the hospital. In most service industries, service quality is the key factor in increasing competitive advantage (Stefan et al., 2016). Research finds that service quality increases customer trust, thus earning SCA (Sweis et al., 2018; Rahmantya \& Djazuli, 2019). Service quality is determined by customers because it conforms to customer specifications rather than company specifications. Good service quality is when a patient's expectation can be met; therefore, if the hospital can guarantee the patient, then the information transfer process is automatically carried out so that the hospital is able to create value for customers, which in turn forms a sustainable competitive advantage. Service quality has five aspects, namely responsiveness, empathy, suitability, reliability, and guarantee/assurance (Sweis et al., 2018)

The social dimension consists of customer satisfaction and loyalty as well as human resources satisfaction. As stated before, customer value is the end of SCA. Hospitals achieve SCA if they have long customer loyalty and high customer satisfaction (Anyim, 2012). The ongoing relationship between healthcare providers and customers is the key factor. Hospitals are advised to provide what patients need and maintain contact, as well as building a good long-term relationship. Human resources satisfaction, as one of the hospital stakeholders, is also as important as customer satisfaction and loyalty to achieve SCA. With the fulfillment of human resource needs, both physically and psychologically, service performance will automatically increase (Stefan et al., 2016). In Gautam and Ghimire (2017) research, psychological satisfaction of human resources brings a positive effect on SCA. Human resource psychological empowerment is deemed to be very effective in developing human resources quality, in which human resources is the main asset in health services.

The strategic dimension consists of service differentiation, innovation, intellectual capital, and marketing. Hospitals must adapt to the customers and implement strategies that can be supportive in a competitive environment, such as service differentiation, diversification, and new product development. However, when the physical product cannot be distinguished easily, the key to success competitive in the service industry lies in the service differentiation so that it can increase other service qualities. Research shows that service differentiation strategies contribute to customer satisfaction and loyalty (Anyim, 2012; Susanto, 2019). The strategy differentiation is carried out by creating differences between competing hospital products. This strategy can expand the hospital business by adding new products/services that are different from others. This will form the hospital's uniqueness so they can reach SCA (Susanto, 2019).

Innovation is a multi-stage process in which organizations turn ideas into new/better products, services, or processes to enhance, compete, and differentiate themselves from others. The intense 
competition encourages hospitals to investigate new opportunities by finding ways and processes in introducing new health services, improving and developing existing health services. Sultan's research found that there is a positive correlation between innovation and SCA achievement. In addition, product and process innovation appear as variables that influence SCA achievement (Mahasneh et al., 2020)

There is an important fact that the real business value is not reflected in material capital but in intellectual capital (Taie, 2014; Stefan et al., 2016). Intellectual capital consists of human resources, structural and relationship capital. Human resources refer to idea capital (labor, employee skills, and knowledge-based attitudes) and leadership capital (experts and managers characteristics). Structural capital refers to innovation capital (patents, trademarks, copyrights, knowledge databases). Relationship capital refers to the relationship with customers, suppliers, and relationships with relationships/members. The results show that intellectual capital assists managers in obtaining valuable resources, which in turn improves performance and receives SCA (Taie, 2014; Ying et al., 2019)

Marketing and technology resources encourage new product development processes so as to increase competitive advantage. Different types of marketing can be a catalyst for different types of sustainability strategies. Furthermore, sustainability strategy is positively related to sustainable consumption behavior/customer loyalty and competitive advantage (Chen \& Liao, 2011; Sharma, 2017). Green marketing is one of the strategies used by the hospital marketing teams nowadays as a key strategy for SCA. One study in India also states that green marketing practices allow hospitals to have a sustainable competitive advantage (Sharma, 2017)

\section{Discussion}

The four dimensions do not necessarily affect the SCA. There are exploratory factors that also have empirical evidence on SCA. The exploratory factor is the contribution of leadership and managerial process to increase the influence of all other factors/dimensions in increasing the competitiveness of a sustainable hospital (Stefan et al., 2016). In Indonesia, the director/manager's role is very crucial.
Studies show that management leadership has a positive and significant effect on company performance. Leaders create goals, values, and systems that lead to continuous performance improvement. Furthermore, the leaders must also be adaptive and be able to develop themselves continuously.

Dynamic changes in government policies require hospitals to be dynamic and evolve. If the Minister of Health Regulation number 3 of 2020 is genuinely ratified, the hospitals need to adjust their strategic plans. The discussions in the Minister of Health Regulation number 3 of 2020 are as follows (Kementerian Kesehatan Republik Indonesia, 2020):

1) INA CBGs are not applicable and replaced by "one tariff." In which in this point, the economic dimension cannot undergo too many changes. This is because $70-80 \%$ of patient visits have been dominated by BPJS users.

2) The types of hospitals are based on the easier service, and in general, the priority is the number of inpatient beds. The classification of General or Special Hospitals should no longer be based on having specialist and sub-specialist medical service capabilities but only based on the number of inpatient beds. This could be an advantage to any type $C$ and $D$ hospitals with many inpatient beds but lack specialist and sub-specialist human resources. In fact, specialists and sub-specialist are rare and concentrated in big cities.

3) There are no more tiered references. Hospitals that provide certain health services are no longer exclusive (only in type A or B General Hospitals or hospitals determined by the government). This policy can be a disadvantage because nowadays, hospitals' competition is very open, and people have the right to choose any hospital.

With all 3 points mentioned above, the directors and managers of any type $C$ and $D$ hospitals can improve the quality dimension by maintaining and improving service performance as well as increasing inpatient beds and strategic dimensions such as providing more services, optimizing human resources, making technological innovation (online queuing service, telemedicine, etc.), marketing, as well as building social dimensions like increasing engagement and service after medication. Meanwhile, any type A or B hospital can improve the quality by keeping/increasing service quality; social dimension 
by maintaining patient and HR engagement; strategic dimension by differentiating services and innovating the process to be more effective and efficient. Of course, tips on achieving SCA must be in line with each hospital. Therefore, positioning (internal and external assessment) is mandatory in changing the strategy step.

This concludes that SCA in the hospital industry is influenced by four dimensions: economic/finance, quality, social, and strategy. Each dimension has both directly and indirectly impact on the SCA. However, without the contribution of good leadership and managerial processes, these four dimensions cannot fully influence the SCA. Therefore, the managers' role is vital in bringing the hospital to SCA through these factors (cost, efficiency, service quality, customers satisfaction and loyalty, human resources satisfaction, service differentiation, innovation, intellectual capital, and marketing).

\section{Declaration of Conflicting Interest}

The authors declare no conflict of interest.

Funding

None.

\section{Author Contributions}

Concept generation, data collection (Marselli), writing and editing of the manuscript (Antono), critically reviewed, writing, and revision (Ayun). All authors agreed with the final version to be published.

\section{Author Biographies}

Marselli Widya Lestari, dr.S.Ked is a Lecturer at Medical Faculty, Universitas Nahdlatul Ulama Surabaya, Indonesia. She currently studies at Magister program in Public Health Faculty, Universitas Diponegoro, Indonesia. Antono Surjoputro, dr. MPH, PHD is a Lecturer at Public Health Faculty, Universitas Diponegoro, Indonesia.

Ayun Sriatmi, dra, Dr, M.Kes is a Lecturer at Public Health Faculty, Universitas Diponegoro, Indonesia.

\section{References}

Anyim, M. A. (2012). Gaining sustainable competitive advantage through service differentiation among private hospitals in Nairobi. University of Nairobi, Kenya.

Chen, S.-H., \& Liao, C.-C. (2011). Are foreign banks more profitable than domestic banks? Home-and hostcountry effects of banking market structure, governance, and supervision. Journal of Banking \& Finance, 35(4), 819-839. https://doi.org/10.1016/ j.jbusres.2011.02.047

Gautam, D. K., \& Ghimire, S. B. (2017). Psychological empowerment of employees for competitive advantages: An empirical study of Nepalese service sector. International Journal of Law and Management. https://doi.org/10.1108/IJLMA-03-2016-0035

Gowen, C. R., McFadden, K. L., \& Settaluri, S. (2012). Contrasting continuous quality improvement, Six Sigma, and lean management for enhanced outcomes in US hospitals. American Journal of Business. https://doi.org/10.1108/19355181211274442

Kementerian Kesehatan Republik Indonesia. (2020). Peraturan Menteri Kesehatan Nomor 30/MENKES/PER/2020 tentang Klasifikasi dan Perizinan Rumah Sakit. Jakarta: Kementerian Kesehatan Republik Indonesia.

Mahasneh, M., Alnahdi, S. A., \& Bani Hani, J. S. (2020). Innovation in health services alignment with the competitive advantage achievement in private hospitals in Saudi Arabia: Strategic evidence. International Journal of Business and Social Science, 11(3), 58-68. https://doi.org/10.30845/ijbss.v11n3p8

Pirayesh, R., \& Forouzandeh, R. (2016). The effective deployment of brand through sustainable competitive advantage and corporate image. Journal of Administrative Management, Education and Training (JAMET), 12(4), 582-592.

Rahmantya, Y. E. K., \& Djazuli, A. (2019). Hospital's competitive advantage through service quality, information systems and Islamic work ethics. Problems and Perspectives in Management, 17(2), 193. https://doi.org/10.21511/ppm.17(2).2019.14

Sharma, A., Iyer, G. R., Hasan, Z., Ali, N. A., Khouildat, S., Zaid, M., Wood, L. C., Wang, C., Abdul-Rahman, H., Jamal Abdul-Nasir, N. S., Sofiyanurriyanti, ., Afifi, I., Amini, A., Widyastuti, S., Said, M., Siswono, S., Dian, Sehgal, P., Saxena, R. P., \& Khandelwal, . (2017). Sustainable development through green marketing. Procedia - Social and Behavioral Sciences. https://doi.org/10.37488/2057-009-001-017

Singh, H., Dey, A. K., \& Sahay, A. (2020). Exploring sustainable competitive advantage of multispecialty hospitals in dynamic environment. Competitiveness Review: An International Business Journal. https://doi.org/10.1108/CR-12-2018-0091

Stefan, S. C., Popa, I., \& Dobrin, C. O. (2016). Towards a model of sustainable competitiveness of health organizations. Sustainability, 8(5), 464. https://doi.org/ 10.3390/su8050464

Susanto, A. (2019). Competitive advantage mitra keluarga hospital surabaya through differentiation and efficiency. RIMA-Research in Management and Accounting, 2(1), 1-7.

Sweis, R. J., Elian, M., Alawneh, A. R., \& Sweis, N. J. (2018). The impact of service quality on sustainable competitive advantage: study on Jordanian health insurance companies. International Journal of Business Excellence, 16(2), 162-176.

Taie, E. S. (2014). The effect of intellectual capital management on organizational competitive advantage 
in Egyptian hospitals. International Journal of Business and Social Science, 5(2).

Ying, Q., Hassan, H., \& Ahmad, H. (2019). The role of a manager's intangible capabilities in resource acquisition and sustainable competitive performance. Sustainability, 11(2), 527. https://doi.org/10.3390/su11 020527

Cite this article as: Lestari, M. W., Surjoputro, A., \& Sriatmi, A. (2021). Sustainable competitive advantage strategy in hospital industry to response policy change in Indonesia: A narrative review. Public Health of Indonesia, 7(3), 95-100. https://dx.doi.org/10.36685/phi.v7i3.421 